\title{
Attitude Towards Advertising: A Young Generation Cohort's Perspective
}

\author{
Hiram Ting \\ Universiti Malaysia Sarawak \\ Ernest Cyril de Run \\ Universiti Malaysia Sarawak
}

\begin{abstract}
This study aims to investigate young consumers' views about advertising from generation perspective. Specifically, it seeks to scrutinize the effects of both advertising beliefs and personal values on their attitude towards advertising. As past studies review little about the implication of generation on advertising attitude in developing markets, the study looks into the subject matter from the standpoint of a young generation cohort in Sarawak. Self-administered survey was utilized on the basis of purposive sampling strategy to sample Neoteric-inheritors (aged 15-21 as of 2013) in the state. 450 copies of questionnaire were distributed, and 384 usable copies were subsequently collected. Data was analyzed using descriptive analysis and regressions. The findings show that product information, social role/image, being good for the economy, not being materialistic and truthfulness have significant effect on Neoteric-inheritors' attitude towards advertising. Contrary to past studies, their advertising attitude is found to be predominantly formed by positive beliefs. Moreover, only internal value is found to be significant in predicting attitude though the effect is weak. The study thus provides insights into how young consumers in developing markets view advertising, and how the understanding of generation articulates the effect of advertising beliefs and personal values on attitude and behavioural intention. By understanding the embedded orientations in generation, knowledge about young consumers' attitude towards advertising, and advertising effectiveness can be further enhanced.
\end{abstract}

Keywords: Young consumer, advertising, value, belief, attitude, generation cohort

\section{Introduction}

Attitude towards advertising is generally accepted as a key indicator to advertising effectiveness (Mehta, 2000) due to its predictive relevance to behaviours (Ling, Piew and Chai, 2010; Mehta and Purvis, 1995). Such attitude is claimed to be mainly constructed by beliefs about advertising (Pollay and Mittal, 1993; Tan and Chia, 2007). When beliefs about advertising change, attitude towards it changes accordingly. It will subsequently affect purchasing intention and behaviours (Wang, Sun, Lei and Toncar, 2009). On another note, personal values are also found to have 
positive relationship with views towards advertising (Brumbaugh, 2002; Kopanidis, 2009; Nairn and Berthon, 2003). Researchers have asserted that personal values provide the best reflection of human behaviours (Pitts and Woodside, 1984) as they are guiding principles in their lives (Seligman and Katz, 1996). Personal values have often been looked into to understand why certain decisions are made (Kamakura and Novak; 1992; White, 2005). Hence, both beliefs about advertising and personal values provide relevant and profound explanation to attitude towards advertising.

Past studies have used different demographic variables to assess how consumers perceive advertising (Butt and de Run, 2010, 2012; Yasin, Anwar and Sajid, 2013). However, little is known about the simultaneous effect of advertising beliefs and values on attitude towards advertising from the perspective of generation (de Run and Ting, 2013). Moreover, given most of the past studies were conducted in western countries, there has been a mounting interest to delve into the subject matter in developing markets (Fam, Waller, Ong and Yang, 2008). Furthermore, while advertising studies using general public as samples are abundant, how adolescents and young adults perceive advertising remains relatively ambiguous as they are largely assumed to be similar to adults (Wang, Holloway, Beatty and Hill, 2007). Taking the Neoteric-inheritors, a young generational cohort in Sarawak, as the target population (Ting, de Run and Fam, 2012), the purpose of this study is to investigate the effects of their beliefs about advertising and personal values on attitude towards advertising. As young consumers in this cohort are still in their formative years, the understanding of their beliefs and values provides fundamental knowledge about their attitude towards advertising and future behaviour (Pechmann, Linda, Loughlin and Frances, 2005; Rogler, 2002).

\section{Literature review}

\section{Attitude towards advertising}

Attitude towards advertising is by and large referred to as response to advertising either in favourable or unfavourable manners (Bamoriya and Singh, 2011). Moreover, attitude towards advertising also reveals the degree of involvement in advertisement (Chowdhury, Parvin, Weitenberner, and Becker, 2010). For example, when consumers express favourable attitude to an advertisement, it indicates that they are highly involved in the advertisement. Furthermore, attitude towards advertising is found to have direct effect on the effectiveness of advertising as it affects consumer purchasing intention and subsequent behaviour (Mehta, 2000; Mehta and Purvis, 1995).

However, past advertising studies do not necessarily show consistent results. Early researchers reported unfavourable attitude towards advertising, thus generating interest to further look into the phenomenon (Alwitt and Prabhaker, 1994; Mittal, 1994). In particular, studies in 1970s revealed negative trends of public attitude towards advertising (Zanot, 1984). Nevertheless, latter researchers advocated that attitude towards advertising in general was found to be largely favourable (Deshpande, Hoyer, and Donthu, 1986; Shavitt, Lowrey, and Haefner, 1998; Valencia, 1985). For example, most Americans were found to have favourable attitude towards advertising as advertisements provided information and entertainment (Shavitt et al., 1998). Notwithstanding the rise of positive attitude, 
mixed results are still evident in recent investigations (Munusamy and Hoo, 2007; Tan and Chia, 2007; Yaakop, Hemsley-Brown, and Gilbert, 2011).

\section{Beliefs about advertising and personal values}

Even though there are several combinations of factors to measure beliefs about advertising in earlier studies, the seven-belief factors model by Pollay and Mittal (1993) is found to be comprehensive and widely used in advertising studies (Korgaonkar, Silverblan and O'Leary, 2001). Hence, the model is adopted in the present study to investigate attitude towards advertising in a developing market. The seven-belief factors consist of two dimensions, namely personal use and societal effect. Personal use is made up by three factors, namely product information, social role/image, and hedonism/pleasure. Societal effect, in turn, is made up by four factors, and they are good for the economy, materialism, falsity/no sense, and value corruption. The inclusion of negative beliefs as shown in the last three factors is pivotal to provide a more holistic understanding of how attitude towards advertising is formed.

In addition to beliefs about advertising, personal value is another antecedent of attitude towards advertising. The List of Values (LOV) is adopted in the study because it is found to be useful in explaining personal values with less complexity, and provides better prediction in consumer behaviour trend (Goldsmith, Freiden and Kilsheimer, 1993; Homer and Kahle, 1988; Kahle, Beatty and Homer, 1986; Novak and MacEvoy, 1990). LOV is composed of three variables, namely internal values, external values, and interpersonal values. Internal value is generally about how a person is internally fulfilled, and it includes self fulfillment, self respect, sense of accomplishment, and excitement. External value, in turn, is more dependent on outside factors, and it includes sense of security, sense of belonging, and being well respected. Lastly, interpersonal value is more concerned with the interaction and communication between individuals, and it is composed of fun and enjoyment in life, and warm relationship.

\section{Generational cohort and Neoteric-inheritors}

Originated from sociology, generational cohort is defined as an individual group, who shares about the same age, born during the same time period, and experiences the similar major external events during the developmental stages (Edmunds and Tuner, 2005; Kupperschmidt, 2000; Smola and Sutton, 2002). Cohort labels, such as Veterans, Baby boomers, Generation X and Generation Y from the U.S sources, have been commonly used to understand consumers in marketing literature (Cennamo and Gardner, 2008; Munusamy et al., 2010; Yu and Miller, 2003). However, cohort labels of one country cannot be generalized to other settings due to differences in historical and societal contexts (de Run and Ting, 2013; Egri and Ralston, 2004; Rogler, 2002). As there is extremely lack of empirical evidence about generational cohorts in developing countries, an exploratory study was first conducted in Malaysia in 2011 as a precursor to future generation studies. It was found that the major external events which are deemed impactful in the country are largely different from that of the U.S. sources (Ting et al., 2012). As a result, different generational cohorts are identified based on their collective experience of the events, and they are labeled as Neotericinheritors (aged 21 and below as of 2013), Prospective-pursuers (aged 22 to 35), 
Social-strivers (aged 36 to 51), Idealistic-strugglers (aged 52 to 70) and battling lifers (aged 71 and above) accordingly. Each cohort has their own characteristics due to their attachment to specific events during formative years (de Run and Ting, 2013; Inglehart, 1997; Rogler, 2002). This study focuses only on Neoteric-inheritors, the young consumers who are still in the adolescence and early adulthood years.

\section{Theoretical foundation}

The Theory of Reasoned Action (TRA) is adapted as the underpinning basis to investigate attitude of Neoteric inheritor towards advertising (Ajzen and Fishbein, 1980). It provides a framework to develop path relationships between belief, attitude and behavioural intention about advertising. While belief serves as the antecedent of attitude, behavioural intention serves as the consequence in the model to enhance the explanation about attitude towards advertising. Behavioural intention is included because it enhances the explanation of attitude and predicts actual behaviour (Jason, Chow and Leitch, 1997). As such, the seven-belief factors model by Pollay and Mittal (1993) is adopted to decompose the construct of belief in TRA. Moreover, since personal values are found to be predictors of attitude, they are also incorporated in the model as another antecedent of attitude towards advertising.

\section{Hypotheses development}

Past studies have clearly established the effect of beliefs about advertising on attitude towards advertising (Eze and Lee, 2012; Pollay and Mittal, 1993; Wolin, Korgaonkar and Lund, 2002; Yaakop et al., 2011). Since the seven-belief factors model is composed of both positive and negative beliefs about advertising (Pollay and Mittal, 1993), all negative beliefs and their statements are re-worded positively in order to formulate one-directional relationship consistently for all hypotheses. As such, hypotheses are developed as follows:

$H_{1}$ : Product information will positively affect attitude of Neoteric-inheritors towards advertising.

$\mathrm{H}_{2}$ : Social role and image will positively affect attitude of Neoteric-inheritors towards advertising.

$\mathrm{H}_{3}$ : Hedonic or pleasure will positively affect attitude of Neoteric-inheritors towards advertising.

$H_{4}$ : Good for the economy will positively affect attitude of Neoteric-inheritors towards advertising.

$H_{5}$ : Not being materialistic (reverse of materialism) will positively affect attitude of Neoteric-inheritors towards advertising.

$H_{6}$ : Truthfulness (reverse of falsity/no sense) will positively affect attitude of Neoteric-inheritors towards advertising.

$H_{7}$ : Not being value corrupted (reverse of value corruption) will positively affect attitude of Neoteric-inheritors towards advertising.

Additionally, past studies have also shown the effect of personal values on attitude (Chaplin and John, 2010; Gurel-Atay, Xie, Chen and Kahle, 2010), and the association between values and advertising views (Brumbaugh, 2002). By using LOV utility, personal values are also postulated to have positive effect on attitude towards advertising. As such, hypotheses are developed as follows: 
$H_{8}$ : Internal values will positively affect attitude of Neoteric-inheritors towards advertising.

$H_{9}$ : External values will positively affect attitude of Neoteric-inheritors towards advertising.

$H_{10}$ : Interpersonal values will positively affect attitude of Neoteric-inheritors towards advertising.

Prior empirical studies have established that when respondents portray positive attitude towards advertising, they tend to reveal favourable intention towards advertising, and act accordingly (Jun and Lee, 2007; Wang and Sun, 2012). Therefore, the last hypothesis is formulated as follows:

$H_{11}$ : Attitude towards advertising will positively affect behavioural intention towards advertising.

\section{Methodology}

Sarawak, the biggest state in Malaysia by size, was chosen as the research site in the study. The state is as diverse as Peninsular Malaysia and Sabah, and has different cultural and historical background. The state is also emerging as a lucrative market due to its strategic location, vast areas and rich resources. Hence, it is of great interest to investigate how advertising is perceived by the younger generation, namely Neoteric-inheritors (aged 21 and below as of 2013), in such a developing market. Given the quantitative nature of the study, self-administered questionnaire was used. Purposive sampling technique was appropriated since the aim was to sample only adolescents and young adults whose age was not more than 21 years old (Burns and Bush, 2005). A pre-test was conducted to ensure the usability of the questionnaire and that potential errors were addressed (Ruyter, Wetzels and Kleijnen, 2001). Eateries, colleges and universities were some of the locations predetermined for distributing questionnaire. Accordingly, 450 copies of questionnaire were distributed throughout Sarawak in October of 2013, and 395 copies were collected in a month time.

In addition to demographics section, the questionnaire had two major sections, firstly to measure belief-attitude-behavioural intention towards advertising, and secondly personal values. 21 statements from the seven-belief factors model by Pollay and Mittal (1993) were adapted to measure beliefs about advertising. In order to allow adjustment of measurement error and better reliability, multiple statements were used for all statements pertaining to advertising (Hair, Hult, Ringle and Sarstedt, 2014). Moreover, 9 statements from the LOV (Kahle et al., 1986) were adopted to measure personal values. These statements were made up by 4 items for measuring internal values, 3 items for measuring external values and 2 items for measuring interpersonal values. A seven-point Likert scale from one end of strong disagreement to another end of strong agreement was used throughout the questionnaire. Statistical Package for Social Sciences (SPSS) was utilized to run reliability test, descriptive analysis, simple and multiple linear regressions. 


\section{Findings}

In the preliminary assessment, non-response bias is not considered as a major issue during the survey due to the high response rate (Parashos, Morgan and Messer, 2005). However, after keying in the data, 9 observations are deemed not usable since their missing data exceeds $15 \%$ of the total items (Hair et al., 2014). Therefore, these observations are removed from the data set. Scattered missing data are then imputed using Expectation Maximization algorithm in SPSS so as to retain all remaining observations to facilitate subsequent analyses (Little and Rubin, 2002).

As a result, the final sample is made up by 384 respondents. Demographic information of respondents is shown in Table 1. Gender, age, race and residence of respondents are provided in the same table to indicate sample characteristics.

Table 1: Respondent Profile

\begin{tabular}{|l|l|c|c|}
\hline \multicolumn{2}{|c|}{ Variable } & Frequency & Percent (\%) \\
\hline \multirow{4}{*}{ Gender } & Male & 164 & 41.0 \\
\cline { 2 - 4 } & Female & 236 & 59.0 \\
\hline & 15 & 51 & 12.8 \\
\cline { 2 - 4 } & 16 & 68 & 17.0 \\
\cline { 2 - 4 } & 17 & 56 & 14.0 \\
\cline { 2 - 4 } & 18 & 58 & 14.5 \\
\cline { 2 - 4 } & 19 & 46 & 11.5 \\
\cline { 2 - 4 } & 20 & 60 & 15.0 \\
\cline { 2 - 4 } & 21 & 61 & 15.3 \\
\hline \multirow{5}{*}{ Race } & Malay & 58 & 14.5 \\
\cline { 2 - 4 } & Chinese & 218 & 54.5 \\
\cline { 2 - 4 } & Iban & 68 & 17.0 \\
\cline { 2 - 4 } & Others & 56 & 14.0 \\
\hline \multirow{5}{*}{ Residence } & Kuching & 238 & 59.5 \\
\cline { 2 - 4 } & Miri & 49 & 12.3 \\
\cline { 2 - 4 } & Sibu & 28 & 7.0 \\
\cline { 2 - 4 } & Bintulu & 19 & 4.8 \\
\cline { 2 - 4 } & Others & 66 & 16.5 \\
\hline
\end{tabular}

Table 2 presents scores for mean and standard deviation of all variables. While product information has the highest mean score for beliefs about advertising, not being materialistic (reverse of materialism), truthfulness (reverse of falsity/no sense) and not being value corrupted (reverse of value corruption) have mean scores below the midpoint. Internal, external and interpersonal values, in turn, share similar mean scores. Moreover, Cronbach alpha is also shown to indicate the reliability of data. Since Cronbach alpha values of 0.7 and above are commonly accepted, alpha value that is below 0.7 may suggest unreliable data (Streiner and Norman, 2008). However, as an alpha value of 0.50 or greater is acceptable for attitude and preference assessments, all the variables are therefore retained (Huang, Lin and Huang, 2012; Tuckman, 1999). 
Table 2: Mean, Standard Deviation and Cronbach Alpha Values

\begin{tabular}{|l|c|c|c|c|}
\hline Variable & Items & Mean & Standard Deviation & Cronbach Alpha \\
\hline Product Information & 3 & 5.46 & 1.02 & 0.833 \\
\hline Social Role/Image & 3 & 4.81 & 1.23 & 0.785 \\
\hline Hedonic/Pleasure & 3 & 4.97 & 1.21 & 0.764 \\
\hline Good for the Economy $^{\text {Materialism }}{ }^{\mathrm{R}}$ & 3 & 4.91 & 1.03 & 0.566 \\
\hline Falsity/ No sense $^{\mathrm{R}}$ & 4 & 3.31 & 1.41 & 0.837 \\
\hline Value Corruption $^{\mathrm{R}}$ & 3 & 3.66 & 1.22 & 0.626 \\
\hline Internal Value $^{\text {External Value }}$ & 2 & 3.68 & 1.39 & 0.808 \\
\hline Interpersonal Value $^{\text {Attitude }}$ & 4 & 5.96 & 0.82 & 0.773 \\
\hline Intention & 3 & 6.06 & 0.85 & 0.783 \\
\hline
\end{tabular}

$\mathrm{R}$ indicates reverse-coding. Hence, Materialism should become Not Being Materialistic, Falsity/No sense become Truthfulness, and Value Corruption become Not Being Value Corrupted.

Table 3 shows that only product information, social role/image, good for the economy, not being materialistic (reverse of materialism) and truthfulness (reverse of falsity/no sense) are found to be significant in regression analysis. Hence, these five beliefs of Neoteric-inheritors have significant effect on their attitude towards advertising. The findings about beta values also indicate that product information and good for the economy have the strongest effect on advertising attitude. The variance explained of over $40 \%$ denotes strong explanatory capacity of the model.

Table 3: Effect of Beliefs on Attitude towards Advertising

\begin{tabular}{|c|c|c|c|}
\hline Variable & Beta & $T$ & Sig. \\
\hline (Constant) & 0.745 & 2.897 & 0.002 \\
\hline Product Information & 0.244 & 5.096 & $0.000 * *$ \\
\hline Social Role and Image & 0.101 & 2.033 & $0.022 *$ \\
\hline Hedonic/ Pleasure & 0.080 & 1.579 & 0.058 \\
\hline Good for the Economy & 0.289 & 6.070 & $0.000 * *$ \\
\hline Materialism $^{\mathrm{R}}$ & 0.096 & 1.860 & $0.032 *$ \\
\hline Falsity/ No sense $^{R}$ & 0.038 & 4.128 & $0.000 * *$ \\
\hline Value Corruption $^{\mathrm{R}}$ & 0.033 & 0.673 & 0.251 \\
\hline $\mathrm{R}^{2}$ & \multicolumn{3}{|c|}{0.414} \\
\hline Adjusted $\mathrm{R}^{2}$ & \multicolumn{3}{|c|}{0.404} \\
\hline $\mathrm{F}$ & \multicolumn{3}{|c|}{39.301} \\
\hline Sig & \multicolumn{3}{|c|}{0.000} \\
\hline Durbin Watson & \multicolumn{3}{|c|}{1.911} \\
\hline
\end{tabular}

$* * \mathrm{p}<0.01, * \mathrm{p}<0.05$ (one-tailed)

$\mathrm{R}$ indicates reverse-coding. Hence, Materialism should become Not Being Materialistic, Falsity/No sense become Truthfulness, and Value Corruption become Not Being Value Corrupted.

Table 4 shows that only internal value is a significant predictor of attitude towards advertising. Additionally, the variance explained is found to be extremely low. Hence, despite being significant, internal value contributes little to explaining attitude of Neoteric-inheritors towards advertising. 
Table 4: Effect of Personal Values on Attitude towards Advertising

\begin{tabular}{|l|c|c|l|}
\hline Variable & $B$ & $t$ & \multicolumn{1}{c|}{ Sig. } \\
\hline (Constant) & 3.319 & 9.159 & 0.000 \\
\hline Internal Value & 0.175 & 2.208 & $0.014^{*}$ \\
\hline External Value & 0.021 & 0.288 & 0.387 \\
\hline Interpersonal Value & 0.032 & 0.423 & 0.336 \\
\hline $\mathrm{R}^{2}$ & \multicolumn{3}{|c|}{0.046} \\
\hline Adjusted $\mathrm{R}^{2}$ & 0.039 \\
\hline $\mathrm{F}$ & \multicolumn{3}{|c|}{6.357} \\
\hline Sig & \multicolumn{3}{|l}{0.000} \\
\hline Durbin Watson & \multicolumn{3}{|l}{1.936} \\
\hline $\mathrm{p}<0.05$ (one-tailed)
\end{tabular}

Table 5 shows that attitude towards advertising significantly affect behavioural intention towards advertising. Variance explained of over $20 \%$ indicates that the effect is moderate, and thus acceptable.

Table 5: Effect of Attitude on Intention towards Advertising

\begin{tabular}{|l|c|r|l|}
\hline \multicolumn{1}{|c|}{ Variable } & $B$ & \multicolumn{1}{c|}{ Sig. } \\
\hline (Constant) & 1.740 & 5.955 & 0.000 \\
\hline Attitude & 0.468 & 10.544 & $0.000^{* *}$ \\
\hline $\mathrm{R}^{2}$ & \multicolumn{3}{|c|}{0.219} \\
\hline Adjusted $\mathrm{R}^{2}$ & 0.217 \\
\hline $\mathrm{F}$ & \multicolumn{3}{|c|}{111.176} \\
\hline Sig & \multicolumn{3}{|c|}{0.000} \\
\hline Durbin Watson & \multicolumn{3}{|c|}{1.749} \\
\hline **p $<0.01$ (one-tailed) &
\end{tabular}

\section{Discussions}

Neoteric-inheritors in Sarawak strongly believe advertising is a provider of product information. Hence, such belief has positive effect on attitude towards advertising. Due to their tender age and inexperience, Neoteric-inheritors tend to look at advertising for information before making purchase. They look for updates through advertisement and consider what is best for them accordingly (Eze and Lee, 2012; Pollay and Mittal, 1993). Without advertising, they feel less confident about the product, and may not consider buying the product at all. Moreover, social role/image is found to have positive effect on Neoteric inheritors' advertising attitude. It is because they are still young and susceptible to change, and hence tend to follow the most current trend of fashion. They believe products shown in recent advertisements are new and fashionable.

In addition to the products that Neoteric-inheritors buy and use, they may also be caught by the lifestyles that advertising portrays (Eze and Lee, 2012). Hence, advertising updates them on recent social image and impress them with personal identity that they admire or aspire to have (Usman, Ilyas, Hussain and Qureshi, 2010). Furthermore, good for the economy is also found to be a significant predictor of advertising attitude because they believe advertising can improve their standard of living by consistently introducing new products to the markets. As most of the young ones are educated, it is relatively easy for them go online to read and understand all the updates, including the latest development of new products (Hess, Magnuson and Beeler, 2012). Past empirical studies have shown evidence to support that advertising 
is often expediting consumer's adoption on just launched products (Eze and Lee, 2012; Pollay and Mittal, 1993; Wang et al, 2009). It shortens the product life cycle and makes the market more competitive. Neoteric-inheritors like to have more alternatives so that they can make switches from one product to another whenever necessary.

Despite using negative advertising beliefs in the study, the findings suggest Neotericinheritors are generally in favour of advertising. Although advertising has often been accused of promoting materialism, they do not regard it as such. In other words, they not only believe advertising is a useful source of product information, it also facilitates purchase decision. In the same vein, Neoteric-inheritors do not see advertising as something falsified. Adolescents and young adults nowadays spend more time in searching advertisement information than older generation (Anwar, 2012). When they expect certain advertising information to be credible, they will spend more time and effort to look into it (Mittal, 1994; Alwitt and Prabhaker, 1992). This may well suggest they are highly selective in advertising that they are interested in. When the information is suspected to be misleading, they will most likely refer to other advertising information for confirmation and more details.

As far as personal values are concerned, the findings show only internal value has positive impact on attitude of Neoteric-inheritors towards advertising. Despite being young, they expect advertisement that they are interested in to fulfill their desires (Homer and Kahle, 1988). They tend to spend more effort on advertisement which they believe is relevant to them, and they hope to get something valuable out of it (Homer and Kahle, 1988). Particularly, they are more easily attracted by advertisements in which the products reflect the identity they possess or are after. Such reaction corresponds to the belief about product information and social role/image of advertising. Hence, internal value is surmised to have close association with product information and social role/image because both affect the manner they want to become and be perceived. Although they are still in their adolescence and early adulthood, they consider self-respect as one of the most important virtues (Gurel-Atay et al., 2010). As they are still coming of age, they want to be conformed to someone that earns respect from others. In other words, they do not want to be treated differently or anyway less than their peers. This might well explain why they can be easily persuaded to buy things that they do not really need in order to have the sense of self-fulfillment or self-accomplishment and to impress others.

However, the findings also indicate that internal value does not contribute much to explaining attitude of Neoteric-inheritors towards advertising. This may due to the fact that they are still in the formative years. Therefore, their personal value is still taking shape, and has not yet consolidated into something permanent. They can still change their views about many things if something cataclysmic happens at the cusp of their growth and development (Rogler, 2002). As a result, their attitude and behavioural intention towards advertising are still gullible to change at their age.

Finally, the behavioural intention of Neoteric-inheritors towards advertising is found to be significantly affected by their attitude towards advertising. It means that when they have favourable attitude towards advertising, their intention towards advertising will also be favourable (Jun and Lee, 2007). Conversely, if they have unfavourable attitude due to negative beliefs about advertising, their intention will likely be 
unfavourable as well. Since they have positive attitude towards advertising, they also have positive behavioural intention towards advertising.

\section{Managerial implication and conclusion}

Understanding consumers' views about advertising in developing markets is of utmost importance in managerial practice. Even though Neoteric-inheritors in Sarawak and Generation Y in the U.S share similar age-range, their beliefs about advertising and value orientation cannot be regarded the same (de Run and Ting, 2013; Zemke, Raines and Filipczak, 2000). Out of the seven-belief factors, only five factors are found to have effect on attitude about advertising in the Sarawakian context. Moreover, contrary to past studies, all these factors show positive relationships with advertising attitude. This suggests that negative advertising, which is more than often used to generate awareness and interest, may not work well with young generation in developing countries. Additionally, only internal value is found to have significant relationship with advertising attitude but the effect is very minimal.

Even though Neoteric-inheritors are young, and most of them have not had their own income, they can be as influential as working adults or their parents. Their views can be decisive in many ways in most families. They can be more opinionate and assertive than young people in the past generations (Dwyer, 2009; Schewe and Meredith, 2004). Hence, failure to keep track of their beliefs and attitude towards advertising may not only lose them as potential buyers and users, it may also cause people around them to be unhelpfully affected. Given the fact that they are potential consumers with growing purchasing ability, it is essential to understand their beliefs about advertising during adolescence and early adulthood years in order to secure favourable attitude and behavioural intention towards advertising in the long run.

Since Neoteric-inheritors are still in the formative years, their personal value may still change over time. This implies that innovative yet appropriate advertising is very much needed to match their beliefs and values today (Mittal, Holbrook, Beatty, Raghubir and Woodside, 2008). As the findings infer the connection between product information, social role/image and internal value, this gives marketers and managers alike a clear indication of what young consumers in Sarawak and emerging markets might be after. Advertising with the right ideas and positive messages will stimulate their interest to find out more about the products and generate favourable impression about the advertisement and the products. Hence, it is pivotal to monitor both the development of their personal values and the impact of any societal change. Tracking personal values of young consumers in such a way will also provide more credible predictions to their attitude and future behaviours towards advertising (Rogler, 2002; Schewe and Meredith, 2004).

Notwithstanding the magnitude of the present study, population and sample under investigation are delimited to Sarawakians. It is because there is no empirical study to date that explicates the actual generational cohorts in Malaysia. Moreover, it is also limited to Neoteric-inheritors who are in their adolescence and early adulthood years. Despite investigating the effect of beliefs about advertising and personal values on advertising attitude, the interacting effect between the two antecedent variables is not assessed. Hence, nationwide studies are needed to firstly explore and identify generational cohorts in Malaysia. This would then allow subsequent studies to be 
carried out to gain insights about attitude towards advertising and specific advertisement, and the implication of generation in a more comprehensive manner. Instead of just looking at one cohort, multi-group comparison between cohorts can also be conducted to extend knowledge pertaining to the effect of generational differences on advertising attitude.

\section{Acknowledgement}

This paper is revised and rewritten based on the paper which won the Best Paper Award at the $6^{\text {th }}$ International Borneo Business Conference (IBBC) organized by the Faculty of Economics and Business, Universiti Malaysia Sarawak on August 20, 2014 in Kuching.

This paper is based on research at Universiti Malaysia Sarawak (UNIMAS) under Fundamental Research Grant Scheme (Grant no: FRGS/2/2013/SS05/UNIMAS/01/1). The authors express their gratitude to Ministry of Higher Education (MOHE) and UNIMAS for sponsoring the research carried out.

\section{References}

Ajzen, I. and Fishbein, M. (1980), Understanding Attitudes and Predicting Social Behavior, Prentice-Hall, London.

Alwitt, L. F. and Prabhaker, P. (1992), "Functional and belief dimension of attitude to TV advertising: Implications for Copytesting", Journal of advertising research, Vol. 32 No.5, pp. 30-42.

Alwitt, L. F. and Prabhaker, P.R. (1994), "Identifying who dislikes television advertising: Not by demographics alone", Journal of Advertising Research, Vol. 34 No. 6, pp. 17-29.

Andersen, K. E. (1972), Introduction to communication theory and practice, Cummings Publishing Company, Inc, California.

Anwar, S. (2012), "Young consumers' attitude towards television advertisements in the internet age", International Journal of Multidisciplinary Research, Vol. 2 No. 4, pp. 201-208.

Bamoriya, H. and Singh, R. (2011), "Information seeking and attitude towards advertising - a cros-sectional empirical study", Journal of Applied Management \& Computer Science, Vol. 3, pp. 1-21.

Brumbaugh, A. M. (2002), "Source and nonsource cues in advertising and their effects on the activtion of cultural and subcultural knowledge on the route to persuasion", Journal of Consumer Research, Vol. 29 No. 2, pp. 258-69.

Burns, A. C. and Bush, R. F. (2005), Marketing Research, Pearson Prentice Hall, Upper Saddle River, NJ.

Cennamo, L. and Gardner, D. (2008), "Generational differences in work values: a study of hospitality management", International Journal of Contemporary Hospitality Management, Vol. 20 No. 6, pp. 595-615.

Chaplin, L. N. and John, D. R. (2010), "Interpersonal influences on adolescent materialism: A new look at the role of parents and peers", Journal of Consumer Psychology, Vol. 20, pp. 176-184.

Chowdhury, H. K., Parvin, N., Weitenberner, C. and Becker, M. (2010), "Consumer attitude toward mobile advertising in an emerging market: An empirical study", Marketing, Vol. 12 No. 2, pp. 206-216. 
de Run, E. C., Butt, M. M., Fam, K. S. and Jong, H. Y. (2010), "Attitudes towards offensive advertising: Malaysian Muslims' views”, Journal of Islamic Marketing, Vol. 1 No.1, pp. 25-36.

de Run, E. C. and Ting, H. (2013), "Generational cohorts and their attitudes toward advertising”, Trziste/Market Journal, Vol. 25 No. 2, pp.143-160.

Deshpande, R., Hoyer, W. D. and Donthu, N. (1986), "The intensity of ethnic affiliation: a study of the sociology of Hispanic consumption", Journal of Consumer Research, Vol. 13, pp. 214-220.

Edmunds, J. and Tuner, B. (2005), "Global generations: social change in the twentieth century", The British Journal of Sociology, Vol. 56 No.4, pp. 559-577.

Eze, U. C. and Lee, C. H. (2012), "Consumers' attitude towards advertising", International Journal of Business and Management, Vol. 7 No. 13, pp. 94108.

Gurel-Atay. E., Xie, G., Chen, J. and Kahle, L. R. (2010), "Changes in social values in the United States: 1976-2007”, Journal of Advertising Research, Vol. 50 No. 1, pp. 57-67.

Hess, R. S., Magnuson, S. and Beeler, L. (2012), Counseling children and adolescents in schools, Sage Publication, U.S.

Homer, P. M. and Kahle, L. R. (1988), "A structural equation test of value-attitudebehavior hierarchy", Journal of Personality and Social Psychology, Vol. 54 No. 4, pp. 638-646.

Huang, E. Y., Lin, S. W. and Huang, T. K. (2012), "What type of learning style leads to online participation in the mixed-mode e-learning environment? A study of software usage instruction", Computers and Education, Vol. 58, pp. 338-349.

Jun, J. and Lee, S. (2007), "Mobile media use and its impact on consumer attitudes toward mobile advertising", International Journal of Mobile Marketing, Vol. 2 No. 1, pp. 50-58.

Kahle, L. R. (1991), "Conceptual and methodological issues in consumer value research", presentation at workshop on values and lifestyle research in marketing, 1991, Brussell, Belgium.

Kahle, L. R., Beatty, S. E. and Homer, P. (1986), "Alternative measurement approaches to consumer values: the list of values (LOV) and values and life style (VALS)", The Journal of Consumer Research, Vol. 13 No. 3, pp. 405409.

Kamakura, W. A. and Novak, T. P. (1992), "Value segmentation: exploring the meaning of LOV", Journal of Consumer Research, Vol. 19, pp. 119-132.

Korgaonkar, P., Silverblan, R. and O'Leary, B. (2001), "Web advertising and Hispanics", Journal of Consumer Marketing, Vol. 18 No. 2, pp. 134-152.

Kopanidis, F. (2009), "Towards the development of a personal values importance scale (PVIS) - application in education", paper presented at Australia New Zealand Marketing Academy (ANZMAC) Conference, Melbourne, Australia.

Kupperschmidt, B. R. (2000), "Multigeneration employees: Strategies for effective management", The Health Care Manager, Vol. 19, pp. 65-76.

Ling, K. C., Piew, T. H. and Chai, L. T. (2010), "The determinants of consumers' attitude towards advertising”, Canadian Social Science, Vol. 6 No. 4, pp. 114126.

Little, R. J. A. and Rubin, D. B. (2002), Statistical Analysis with Missing Data, 2nd ed., John Wiley, New York.

Ma, M. (2008), "The relationship between personal-oriented values, attitude towards, and purchase intention of facial whitening products: A study of Thai male 
consumers in Bangkok, Thailand", Au Journal of Management, Vol. 6 No. 2, pp. 1-9.

Mehta, A. (2000), "Advertising attitudes and advertising effectiveness", Journal of Advertising Research, Vol. 1, pp. 67-72.

Mehta, A. and Purvis, S. C. (1995), "When attitudes towards advertising in general influence advertising success", paper presented at The Conference of the American Academy of Advertising, Norfolk, VA.

Mittal, B. (1994). "Public assessment of TV advertising: Faint praise and harsh criticism", Journal of Advertising Research, Vol. 34 No. 1, pp. 35-53.

Munusamy, K., Arumugam, T. and Rahim, F. A. (2010), "Perceived differences in values among baby boomers, Gen-X and Gen-Y: A survey on academicians", paper presented at The International Conference in Business and Economics Research (ICBER), Kuching, Sarawak, Malaysia.

Munusamy, J. and Hoo, W. C. (2007), "Attitude towards advertising among students at private higher learning institutions in Selangor", UNITAR E-Journal, Vol. 3 No. 1, pp. 31-51.

Nairn, A. and Berthon, P. (2003), "Creating the customer: The influence of advertising on consumer market segments - evidence and ethics", Journal of Business Ethics, Vol. 42 No. 1, pp. 83-99.

Parashos, P., Morgan, M. V. and Messer, H. H. (2005), "Response rate and nonresponse bias in a questionnaire survey of dentist", Community Dentistry and Oral Epidemiology, Vol. 33, pp. 9-16.

Pechmann, C., Linda, L., Loughlin, S. and Frances, L. (2005), "Impulsive and selfconscious: Adolescent's vulnerability to advertising and promotion", Journal of Public Policy and Marketing, Vol. 24 No. 2, pp. 202-221.

Pitts, R. E. and Woodside, A. (1984), "Personal values and market segmentation: Applying the value construct", in Pitts, R. and Woodside, A. (Eds), Personal Values and the Consumer Psychology, Lexington Books, Lexington, MA, pp. 55-67.

Pollay, R., W. and Mittal, B. (1993), "Here's the Beef: Factors, Determinants, and Segments in Consumer Critism of Advertising", Journal of Marketing, Vol. 57, pp. 99-114.

Ruyter, J. C. de, Wetzels, M. G. M. and Kleijnen, M. (2001), "Customer adoption of e-service: An experimental study", International Journal of Service Industry Management, Vol. 12 No. 2, pp. 184-207.

Seligman, C. and Katz, A. N. (1996), "The dynamics of value systems," in Seligman, C., Olson, J. M. and Zanna, M. P. (eds), The Ontario Symposium: The Psychology of Values, Mahwah, NJ: Erlbaum, pp. 53-75.

Shavitt, S., Lowrey, P. and Haefner, J. (1998), "Public attitudes toward advertising: More favorable than you might think", Journal of Advertising Research, Vol. 38 No. 4, pp. 7-22.

Smola, K. W. and Stutton, C. D. (2002), "Generational differences: Revisiting generational work values for the new millennium", Journal of Organizational Behavior, Vol. 23, pp. 363-382.

Streiner, D. L. and Norman, G. R. (2008), Health Measurement Scales. A Practical Guide to Their Development and Use, 4th ed., Oxford University Press, Oxford.

Tan, S. J. \& Chia, L. (2007), "Are we measuring the same attitude? Understanding media effects on attitude towards advertising", Marketing Theory, Vol. 7 No. 4, pp. 353-377. 
Ting, H., de Run, E. C. and Fam, K. S. (2012), "Identifying generational cohorts in Sarawak", paper presented at the International Borneo Business Conference, Tawau, Sabah.

Tuckman, B. W. (1999), Conducting Educational Research, Wadsworth Group, Belmont, CA.

Usman, M., Ilyas, S., Hussain, M. F. and Qureshi, T. M. (2010), "General attitude towards advertising: Cultural influence in Pakistan”, International Journal of Marketing Studies, Vol. 2 No. 2, pp. 124-133.

Valencia, H. (1985), "Developing an index to measure Hispanicness", Advances in consumer research, Vol. 12 No. 1, pp. 118-121.

Wang, S., Holloway, B. B., Beatty, S. E., and Hill, W. W. (2007), "Adolescent influence in family purchase decisions: An update and cross-national extension", Journal of Business Research, Vol. 4 No. 4, pp. 1-8.

Wang, Y. and Sun, S. (2010), "Examining the role of beliefs and attitudes in online advertising: a comparison between the USA and Romania", International Marketing Review, Vol. 27 No. 1, pp. 87-107.

Wang, Y., Sun, S., Lei, W. and Toncar, M. (2009), "Examining beliefs and attitudes toward online advertising among Chinese consumers", Direct Marketing: An International Journal, Vol. 3 No. 1, pp. 52-66.

White, C. (2005), "Towards an understanding of the relationship between work values and cultural orientations within the student decision making process", Journal of Further and Higher Education, Vol. 27 No. 3, pp. 271-287.

Wolin, L., Korgaonkar, P. and Lund, D. (2002), "Beliefs, attitudes and behavior towards web advertising”, International Journal of Advertising, Vol. 21 No. 1, pp. 87-113.

Yaakop, A. Y., Hemsley-Brown, J. and Gilbert, D. C. (2011), "Attitudes towards advertising Malaysians vs. non-Malaysians", Asian Journal of Business and Management Science, Vol. 1 No. 2, pp. 77-94.

Zanot, E. (1984), "Public Attitude toward Advertising: The American Experience", International Journal of Advertising, Vol. 3 No. 1, pp. 3-15. 